\title{
Australian Journal of \\ Silicon (Si) reduces the effects of salt stress on germination and initial growth of lettuce (Lactuca sativa L.)
}

\author{
Hozano de Souza Lemos Neto $^{1^{*}}$, Marcelo de Almeida Guimarães ${ }^{1}$, Italo Marlone Gomes Sampaio ${ }^{2}$, Ana \\ Régia Alves de Araújo Hendges ${ }^{3}$, Alexandre Bosco de Oliveira ${ }^{1}$, Sebastião Medeiros Filho ${ }^{1}$
}

\author{
${ }^{1}$ Universidade Federal do Ceará, Centro de Ciências Agrárias, Departamento de Fitotecnia. 60356-001, Fortaleza, \\ Ceará, Brazil \\ ${ }^{2}$ Universidade Federal Rural da Amazônia, Instituto de Ciências Agrárias, Departamento de Solos, Belém, Pará, \\ Brazil \\ ${ }^{3}$ Instituto Federal de Educação, Ciência e Tecnologia do Maranhão. 65.840-000, São Raimundo das Mangabeiras, \\ Maranhão, Brazil \\ *This work is part of the doctoral thesis of the first author \\ *Corresponding author: hozanoneto@hotmail.com
}

\begin{abstract}
Salinity is one of the abiotic stresses that most limit crop productivity. This makes it essential to search for alternatives that would ensure the viability of production under such conditions. The aim of this work was to evaluate the potential of silicon for reducing the detrimental effects of salt stress on seed germination and initial seedling growth in five lettuce cultivars. Two experiments were carried out in a completely randomised design with four replications. In the first experiment, germination behaviour of five lettuce cultivars (Year Round Cabbage, Americana Great Lakes, Great Lakes 659, Lucy Brown, and Crisp Cabbage) was evaluated under five levels of salt stress $(0,50,100,150$ and $200 \mathrm{mM})$. In the second, two lettuce cultivars, one sensitive and one tolerant to salinity, submitted to six different combinations of $\mathrm{NaCl}$ and $\mathrm{Na}_{2} \mathrm{SiO}_{3}$. The germination (G), first germination count, germination speed index, mean germination time, and root and shoot length and dry weight were evaluated. A reduction in $\mathrm{G}$ was seen from $100 \mathrm{mM}$ for all cultivars, with 'Lucy Brown' being the most tolerant, even under higher levels of $\mathrm{NaCl}$. The 'Americana Great Lakes' and 'Great Lakes 659' were the most sensitive to salinity. When silicon was added to the $\mathrm{NaCl}$ treatments, it was found that the effects of the salt stress were reduced, resulting in higher values for germination and the growth variables. Silicon reduced the detrimental effects of salt stress on the physiological quality of the seeds and the initial growth phase of the lettuce.
\end{abstract}

Keywords: Lactuca sativa L.; salt stress; cultivar; sodium silicate; $\mathrm{NaCl}$.

Abbreviations: $\mathrm{NaCl}$ _Sodium chloride, $\mathrm{Si}$ _silicon, $\mathrm{Na}_{2} \mathrm{SiO}_{3}$ _sodium silicate, $\mathrm{mM}$ _millimolar, $\mathrm{MPa}$ _megapascal.

Introduction

Salinity affects plant germination and growth by reducing the osmotic potential of the soil and consequently the water potential, which hampers water absorption by the seeds. There are also the effects of toxic ions that when absorbed by the embryo, can inhibit the synthesis and/or activity of hydrolytic enzymes necessary for germination (Yokoi et al., 2002; Munns and Tester, 2008). Osmotic stress has the most pronounced effect on the physiological quality of the seeds, with limitations on the imbibition phase so that the amount of water reaching the embryo cells is reduced, decreasing the speed and percentage of germination (Gupta and Huang, 2014).

Among the studies which aim to assure the viability of using areas of salinity, is the use of cultivars tolerant to salt stress, as well as the use of agronomic management techniques that minimise these effects. Among the management techniques which aim for tolerance to abiotic stress, it is important to highlight the use of silicon fertiliser, seen as a promising technology for achieving this objective (Rizwan et al., 2015).

Although not considered an essential element, silicon has shown several effects which are beneficial to plants, including a reduction in leaf transpiration; an increase in chlorophyll content; an increase in the mechanical resistance of the cells, leaving the leaves more upright; greater $\mathrm{CO}_{2}$ absorption; and higher rates of photosynthesis. These physiological changes allow a reduction in the effects of such abiotic stresses as water deficit, metal toxicity, salinity, etc. In addition, this element is involved in increasing resistance to pests and diseases by the formation of a mechanical barrier in the plants, making attacks by plant disease difficult (Rodrigues et al., 2011; Lima et al., 2011: Rizwan et al., 2015). 
Some researchers have used silicon to produce various species grown under saline conditions, among which positive results can be found in the literature for the cashew (Anacardium occidentale L.) (Miranda et al., 2010), rice (Oriza sativa L.) (Kraska and Breitenbeck, 2010), maize (Zea mays L.) (Lima et al., 2011), wheat (Triticum aestivum L.) (Tuna et al., 2008; Gurmani et al., 2013), sorghum (Sorghum bicolor (L.) moench.) (Kafi et al., 2011), and rapeseed (Brassica napus L.) (Farshidi et al., 2012).

However, although the use of silicon to reduce the effects of salinity on seed germination has already been confirmed in such crops as the tomato (Solanum lycopersicum L.) (Almutairi, 2016) and Momordica charantia (Wang et al. al., 2010), for most vegetables, research which uses this nutrient as an alternative for reducing the negative effects of salinity is still scarce. For lettuce, such studies are even more limited, and no research is known to address the subject; studies that investigate the behaviour of silicon in reducing the effects of salinity in this species are therefore important. Based on the above, the aim of this work was to evaluate the use of silicon to reduce the effects of salt stress on seed germination and initial seedling growth in five lettuce cultivars.

\section{Results and Discussion}

\section{Germination and initial growth in different lettuce cultivars under salinity}

From a summary of the analysis of variance (ANOVA), an interaction $(p \leq 0.05)$ was seen between cultivar and salinity for all the characteristics being evaluated. Accordingly, the factors were broken down and their behaviour studied for each characteristic.

In general, all cultivars showed satisfactory germination (G), more than $82 \%$ up to the concentration of $100 \mathrm{mM} \mathrm{NaCl}$ (Table 1). At the concentration of $150 \mathrm{mM}$, the cultivars 'Year Round Cabbage' (C1) and 'Lucy Brown' (C4) presented the highest mean values, showing the greatest tolerance. The cultivar, 'Americana Great Lakes', was the most affected at this concentration, and was considered sensitive. At the maximum stress of $200 \mathrm{mM}$, none of the cultivars presented satisfactory G. For germination speed index (GSI), first germination count (FGC) and mean germination time (MGT), the same behaviour was seen as for $\mathrm{G}$, with a reduction only from the concentration of $100 \mathrm{mM}$ for all cultivars.

The cultivars showed a varying response to stress, with some, such as ' $\mathrm{C} 1$ ' and ' $\mathrm{C} 4$ ', being more tolerant and others, such as Great Lakes 659 (C3), being were more sensitive. This difference in behaviour agrees with Oliveira and Gomes Filho (2009), who evaluated the effects of both water and salt stress on germination and vigour in seeds of two genotypes of forage sorghum, and found that the genotypes had varying responses to the the different conditions of salt and water deficit to which they were submitted.

In general, a quadratic regression model was found to fit the variables $\mathrm{G}, \mathrm{FGC}$ and $\mathrm{MGT}$ as a function of $\mathrm{NaCl}$ levels (Figures $1 \mathrm{a}, 1 \mathrm{~b}$ and $1 \mathrm{~d}$ ), with a marked decrease in these variables from $100 \mathrm{mM}$ of $\mathrm{NaCl}$, irrespective of the cultivar under evaluation.

The cultivar 'Lucy Brown' (C4) proved to be the most tolerant at the highest levels of $\mathrm{NaCl}$, reaching $100 \% \mathrm{G}$ at
$62.41 \mathrm{mM} \mathrm{NaCl}$, followed by 'Year Round Cabbage' (C1) with $97 \% \mathrm{G}$ at a level of $51.45 \mathrm{mM}$ (Figure 1a), while 'Americana Great Lakes' (C2) and 'Great Lakes 659' (C3) were the most sensitive. For $\mathrm{FGC}$, the maximum for $\mathrm{C} 1$ was $93.51 \%$ at a level of $49.19 \mathrm{mM} \mathrm{NaCl}$, and for $\mathrm{C} 4$ the maximum was $100 \%$ at $61.71 \mathrm{mM}$ (Fig 1b).

The lettuce seeds from the different cultivars studied in this work showed greater germination capability in treatments where the concentration of $\mathrm{Na}$ and $\mathrm{Cl}$ ions was below 100 $\mathrm{mM}$; above this level there was a reduction in germination and GSI. This behaviour was also seen in seeds of the sunflower and moringa, which followed a quadratic behaviour when submitted to different salt concentrations, with a decrease in germination only seen from $50 \mathrm{~mol} . \mathrm{m}^{-3}$ $\mathrm{NaCl}$ (Santos et al., 2011; Rabbani et al., 2013). Nasri et al. (2015) also reported a reduction in germination percentage at a level of $100 \mathrm{mM} \mathrm{NaCl}$ in lettuce cultivars.

Evaluating physiological seed quality in Brassica pekinensis Rupr. under conditions of salt stress at concentrations of 0.2 to $0.8 \mathrm{MPa}$, Lopes and Macedo (2008) found that salinity affected the expression of physiological potential through the germination and vigour of the seeds in Chinese cabbage. Damage caused by salinity was proportional to the reduction in osmotic potential of the medium in which the seeds were placed for germination. This behaviour is due to the fact that, when germinated under conditions of salt stress, the seeds suffer from the osmotic effect, i.e. they absorb less water during the imbibition phase of the seed, which leads to reduced germination (Yokoi et al., 2002; Munns and Tester, 2008).

The effects of salt stress during the germination phase are due to a reduction in water absorption by the seeds (Gupta and Huang, 2014) as well as to toxic effects, with plant sensitivity to higher or lower concentrations of salts in the substrate being a characteristic of the species, the cultivar, the type of salt, the period of exposure to stress, and the phenological stage of the plant (Bray et al., 2015). Such was confirmed in this work, where the cultivars $\mathrm{C} 1$ and $\mathrm{C} 4$ were the most tolerant to the effects of $\mathrm{NaCl}$ concentration.

For GSI there was a linear decrease as a function of the increase in the $\mathrm{NaCl}$ concentration (Figure 1c); for MGT the fit was quadratic, with a reduction beginning at $100 \mathrm{mM}$ for all cultivars (Figure $1 \mathrm{~d}$ ). The cultivars $\mathrm{C} 1$ and $\mathrm{C} 4$ took the most time to germinate, 6.64 and 6.98 days respectively. Therefore, as the salt concentration of the germination medium increases, there is greater limitation on water absorption by the seeds, and consequently a reduction in the speed of germination, resulting in more time being necessary for the seeds to germinate. Bernardes et al. (2015) found that in cabbage seeds (Brassica oleracea) the GSI also decreased with a reduction in osmotic potential, i.e. with an increase in the levels of $\mathrm{NaCl}$.

The ' $\mathrm{C} 1$ ' and ' $\mathrm{C} 4$ ' cultivars presented the greatest values for seedling root and shoot length and dry weight at levels of 100 and $150 \mathrm{mM}$ (Table 2). At the maximum stress of 200 $\mathrm{mM}$, there was no growth of either the primary root or the shoots. When working with different accessions of the 'Gaúcho Redondo' and 'AF682' melon cultivars, Secco et al. (2010a) found a reduction in total seedling length when these were exposed to salt stress. 
Table 1. Mean values for germination (G), germination speed index (GSI), first germination count (FGC) and mean germination time (MGT), in seeds of five lettuce cultivars under different levels of salinity.

\begin{tabular}{|c|c|c|c|c|c|c|}
\hline \multirow{2}{*}{$\begin{array}{l}\text { Germination (\%) } \\
\text { Cultivar }\end{array}$} & \multicolumn{5}{|c|}{ Levels of $\mathrm{NaCl}(\mathrm{mM})$} & \multirow[t]{2}{*}{ C.V. (\%) } \\
\hline & 0 & 50 & 100 & 150 & 200 & \\
\hline Year Round Cabbage & $89 \mathrm{~b}$ & $96 a$ & $91 \mathrm{~b}$ & $66 \mathrm{~b}$ & $28 \mathrm{~b}$ & \\
\hline Americana Great lakes & $100 \mathrm{a}$ & $100 \mathrm{a}$ & $92 \mathrm{~b}$ & $2.0 \mathrm{~d}$ & $0.00 \mathrm{c}$ & \\
\hline Great Lakes 659 & $100 \mathrm{a}$ & 98 a & $82 \mathrm{c}$ & $8.0 \mathrm{~d}$ & $0.00 \mathrm{c}$ & 9.88 \\
\hline Lucy Brown & $100 \mathrm{a}$ & $100 \mathrm{a}$ & 99 a & 96 a & 46 a & \\
\hline Crisp Cabbage & 99 a & 97 a & $96 \mathrm{~b}$ & $13 \mathrm{c}$ & $0.00 \mathrm{c}$ & \\
\hline \multicolumn{7}{|l|}{ IVG } \\
\hline Cultivar & 0 & 50 & 100 & 150 & 200 & \\
\hline Year Round Cabbage & $79.30 \mathrm{~d}$ & $74.50 \mathrm{c}$ & $68.38 \mathrm{~b}$ & $46.99 \mathrm{~b}$ & $13.54 \mathrm{a}$ & \\
\hline Americana Great lakes & 129.64 a & 102.88 a & $53.83 \mathrm{c}$ & $0.40 \mathrm{c}$ & $0.00 \mathrm{~b}$ & \\
\hline Great Lakes 659 & $120.50 \mathrm{~b}$ & 104.11 a & $44.07 \mathrm{~d}$ & $1.39 \mathrm{c}$ & $0.00 \mathrm{~b}$ & 7.44 \\
\hline Lucy Brown & $108.89 \mathrm{c}$ & $92.18 \mathrm{~b}$ & $78.47 \mathrm{a}$ & $57.93 \mathrm{a}$ & $17.90 \mathrm{a}$ & \\
\hline Crisp Cabbage & $122.90 \mathrm{~b}$ & $93.99 \mathrm{~b}$ & $64.05 \mathrm{~b}$ & $3.31 \mathrm{c}$ & $0.00 \mathrm{~b}$ & \\
\hline \multicolumn{7}{|l|}{ FGC (\%) } \\
\hline Cultivar & 0 & 50 & 100 & 150 & 200 & \\
\hline Year Round Cabbage & $87 \mathrm{~b}$ & $91 \mathrm{c}$ & $88 \mathrm{~b}$ & $64 \mathrm{~b}$ & $25 a$ & \\
\hline Americana Great lakes & $100 \mathrm{a}$ & $100 \mathrm{a}$ & $78 \mathrm{c}$ & $0 \mathrm{~d}$ & $0 \mathrm{~b}$ & \\
\hline Great Lakes 659 & $98 \mathrm{a}$ & $97 b$ & $72 \mathrm{c}$ & $0 d$ & $0 \mathrm{~b}$ & 9.41 \\
\hline Lucy Brown & $100 \mathrm{a}$ & $100 \mathrm{a}$ & 99 a & 95 a & 35 a & \\
\hline Crisp Cabbage & $98 \mathrm{a}$ & $96 \mathrm{~b}$ & $91 \mathrm{~b}$ & $4 \mathrm{c}$ & $0 \mathrm{~b}$ & \\
\hline \multicolumn{7}{|l|}{ MGT (days) } \\
\hline Cultivar & 0 & 50 & 100 & 150 & 200 & \\
\hline Year Round Cabbage & 4.99 a & $6.75 \mathrm{a}$ & $6.50 \mathrm{a}$ & $4.68 \mathrm{~b}$ & $2.00 \mathrm{~b}$ & \\
\hline Americana Great lakes & $0.00 \mathrm{~d}$ & $3.71 \mathrm{c}$ & $6.57 a$ & $0.11 \mathrm{e}$ & $0.00 \mathrm{c}$ & \\
\hline Great Lakes 659 & $1.00 \mathrm{c}$ & $2.90 \mathrm{~d}$ & $5.86 a$ & $0.54 \mathrm{~d}$ & $0.00 \mathrm{c}$ & 12.26 \\
\hline Lucy Brown & $2.96 \mathrm{~b}$ & $5.29 \mathrm{~b}$ & 7.07 a & $6.86 \mathrm{a}$ & $3.24 \mathrm{a}$ & \\
\hline Crisp Cabbage & $0.57 \mathrm{c}$ & $4.25 \mathrm{c}$ & $6.82 \mathrm{a}$ & $0.93 \mathrm{c}$ & $0.00 \mathrm{c}$ & \\
\hline
\end{tabular}

Mean values followed by the same letter in a column do not differ them by Scott-Knott test at a significance level of 5\%.
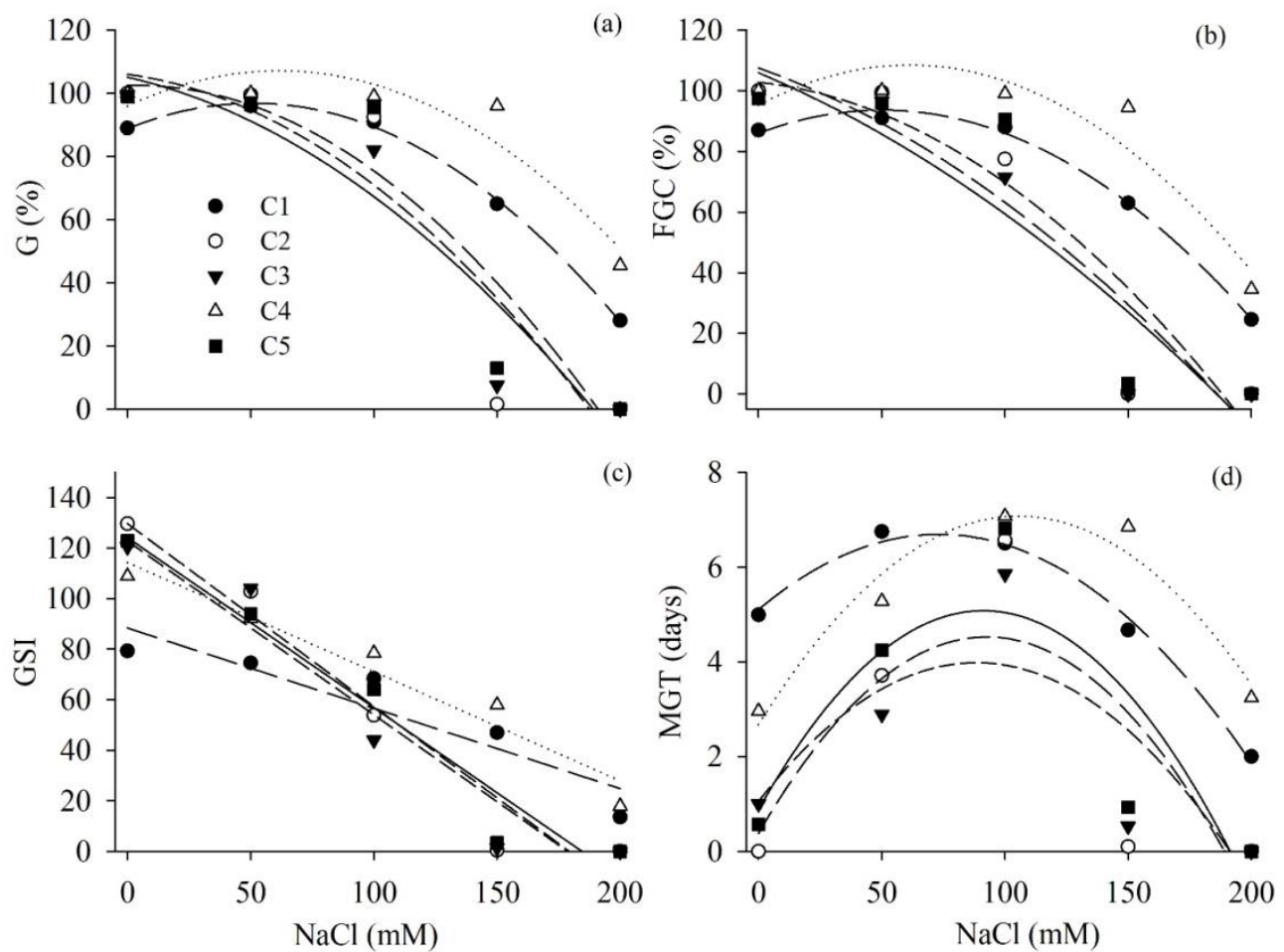

Fig 1. Germination performance in seeds of five lettuce cultivars submitted to different levels of $\mathrm{NaCl}$ : (a): germination (G), (b): first germination count (FGC), (c): germination speed index (GSI) and (d): mean germination time (MGT). 
Table 2. Mean values for root length (RL), shoot length (SL), root dry weight (RDW) and shoot dry weight (SDW), in seeds of five lettuce cultivars under different levels of salinity.

\begin{tabular}{|c|c|c|c|c|c|c|}
\hline \multirow{2}{*}{$\begin{array}{l}\text { RL (cm) } \\
\text { Cultivar }\end{array}$} & \multirow[b]{2}{*}{0} & \multicolumn{4}{|c|}{ Levels of $\mathrm{NaCl}(\mathrm{mM})$} & \multirow[t]{2}{*}{ C.V. (\%) } \\
\hline & & 50 & 100 & 150 & 200 & \\
\hline Year Round Cabbage & $3.34 \mathrm{c}$ & $2.79 \mathrm{a}$ & $1.91 \mathrm{a}$ & $1.23 \mathrm{a}$ & $0.63 a$ & \\
\hline Americana Great lakes & $4.58 \mathrm{a}$ & $2.03 \mathrm{~b}$ & $1.38 \mathrm{c}$ & $0.00 \mathrm{~b}$ & $0.00 \mathrm{~b}$ & \\
\hline Great Lakes 659 & $3.99 \mathrm{~b}$ & $2.23 \mathrm{~b}$ & $1.26 \mathrm{c}$ & $0.00 \mathrm{~b}$ & $0.00 \mathrm{~b}$ & 4.75 \\
\hline Lucy Brown & $3.11 \mathrm{c}$ & $2.17 \mathrm{~b}$ & $2.04 \mathrm{a}$ & $1.40 \mathrm{a}$ & $0.00 \mathrm{~b}$ & \\
\hline Crisp Cabbage & $3.79 \mathrm{~b}$ & $1.98 \mathrm{~b}$ & $1.65 \mathrm{~b}$ & $0.00 \mathrm{~b}$ & $0.00 \mathrm{~b}$ & \\
\hline \multicolumn{7}{|l|}{$\mathrm{SL}(\mathrm{cm})$} \\
\hline Cultivar & 0 & 50 & 100 & 150 & 200 & \\
\hline Year Round Cabbage & $1.95 \mathrm{a}$ & $1.56 \mathrm{a}$ & $1.21 \mathrm{a}$ & $0.75 \mathrm{a}$ & $0.41 \mathrm{a}$ & \\
\hline Americana Great lakes & $0.35 c$ & $0.32 \mathrm{c}$ & $0.28 \mathrm{c}$ & $0.00 \mathrm{c}$ & $0.00 \mathrm{~b}$ & \\
\hline Great Lakes 659 & $0.43 c$ & $0.35 c$ & $0.26 c$ & $0.00 \mathrm{c}$ & $0.00 \mathrm{~b}$ & 2.68 \\
\hline Lucy Brown & $1.15 \mathrm{~b}$ & $0.98 \mathrm{~b}$ & $0.89 \mathrm{~b}$ & $0.61 \mathrm{~b}$ & $0.00 \mathrm{~b}$ & \\
\hline Crisp Cabbage & $0.42 c$ & $0.40 \mathrm{c}$ & $0.34 \mathrm{c}$ & $0.00 \mathrm{c}$ & $0.00 \mathrm{~b}$ & \\
\hline \multicolumn{7}{|l|}{ RDW (mg) } \\
\hline Cultivar & 0 & 50 & 100 & 150 & 200 & \\
\hline Year Round Cabbage & $3.10 \mathrm{~b}$ & $3.20 \mathrm{c}$ & $4.57 \mathrm{a}$ & $1.93 \mathrm{a}$ & $0.96 a$ & \\
\hline Americana Great lakes & $4.17 \mathrm{a}$ & $3.15 c$ & $2.42 \mathrm{~d}$ & $0.00 \mathrm{~b}$ & $0.00 \mathrm{~b}$ & \\
\hline Great Lakes 659 & $3.60 \mathrm{~b}$ & $3.87 \mathrm{~b}$ & $2.83 \mathrm{c}$ & $0.00 \mathrm{~b}$ & $0.00 \mathrm{~b}$ & 6.14 \\
\hline Lucy Brown & $4.20 \mathrm{a}$ & $4.67 \mathrm{a}$ & $3.57 \mathrm{~b}$ & $2.10 \mathrm{a}$ & $0.00 \mathrm{~b}$ & \\
\hline Crisp Cabbage & $4.60 \mathrm{a}$ & $3.40 \mathrm{c}$ & $2.07 \mathrm{~d}$ & $0.00 \mathrm{~b}$ & $0.00 \mathrm{~b}$ & \\
\hline \multicolumn{7}{|l|}{ SDW (mg) } \\
\hline Cultivar & 0 & 50 & 100 & 150 & 200 & \\
\hline Year Round Cabbage & $11.22 \mathrm{a}$ & $13.90 \mathrm{a}$ & $12.63 \mathrm{a}$ & $13.65 \mathrm{a}$ & $8.17 \mathrm{a}$ & \\
\hline Americana Great lakes & $6.15 b$ & $7.35 \mathrm{c}$ & $6.50 \mathrm{c}$ & $0.00 \mathrm{c}$ & $0.00 \mathrm{~b}$ & \\
\hline Great Lakes 659 & $6.12 \mathrm{~b}$ & $7.25 \mathrm{c}$ & $8.10 \mathrm{~b}$ & $0.00 \mathrm{c}$ & $0.00 \mathrm{~b}$ & 5.13 \\
\hline Lucy Brown & $11.80 \mathrm{a}$ & $10.82 \mathrm{~b}$ & $13.20 \mathrm{a}$ & $11.06 \mathrm{~b}$ & $0.00 \mathrm{~b}$ & \\
\hline Crisp Cabbage & $5.90 \mathrm{~b}$ & $8.12 \mathrm{c}$ & $8.93 \mathrm{~b}$ & $0.00 \mathrm{c}$ & $0.00 \mathrm{~b}$ & \\
\hline
\end{tabular}

Mean values followed by the same letter in a column do not differ them by Scott-Knott test at a significance level of $5 \%$.
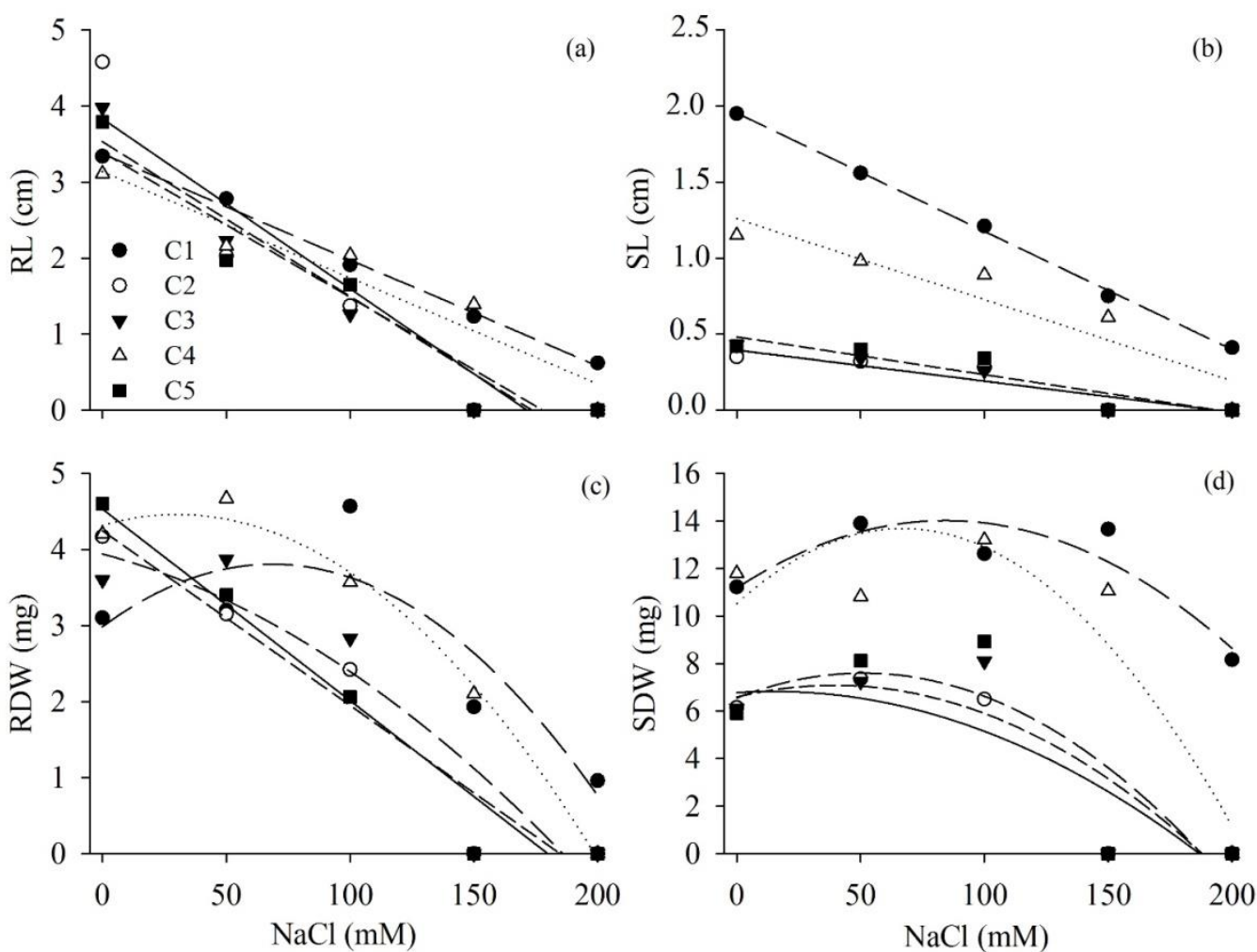

Fig 2. Initial growth in seedlings of five lettuce cultivars submitted to different levels of $\mathrm{NaCl}$ : (a) root length (RL), (b): shoot length (SL), (c) root dry weight (RDW) and (d): shoot dry weight (SDW) 
Table 3. Equations for germination, first germination count (FGC), germination speed index (GSI), mean germination time (MGT) and coefficient of determination $\left(\mathrm{R}^{2}\right)$, in seeds of five lettuce cultivars submitted to different levels of $\mathrm{NaCl}$.

\begin{tabular}{|c|c|c|}
\hline Germination (\%) & Response function & $\mathrm{R}^{2}$ \\
\hline Year Round Cabbage (C1) & $y=88.82^{* *}+0.319^{* *} x-0.0031^{* *} x^{2}$ & 0.99 \\
\hline Americana Great Lakes (C2) & $y=106.01 * *-0.104 x-0.0025 * * x^{2}$ & 0.91 \\
\hline Great Lakes 659 (C3) & $y=105.10 * *-0.178 * * x-0.0020 * * x^{2}$ & 0.94 \\
\hline Lucy Brown (C4) & $y=95.98^{* *}+0.362^{* *} x-0.0029 * * x^{2}$ & 0.94 \\
\hline Crisp Cabbage (C5) & $y=102.45^{* *}+0.022 x-0.0029 * * x^{2}$ & 0.93 \\
\hline FGC (\%) & Response function & \\
\hline Year Round Cabbage (C1) & $y=86.01^{* *}+0.305^{* *} x-0.0031^{* *} x^{2}$ & 0.99 \\
\hline Americana Great Lakes (C2) & $y=107.51 * *-0.287^{* *} x-0.0016^{* *} x^{2}$ & 0.93 \\
\hline Great Lakes 659 (C3) & $y=105.92 * *-0.344 * * x-0.0012 * * x^{2}$ & 0.93 \\
\hline Lucy Brown (C4) & $y=95.25 * *+0.432 * * x-0.0035^{* *} x^{2}$ & 0.94 \\
\hline Crisp Cabbage (C5) & $y=102.78 * *-0.086 * * x-0.0024 * * x^{2}$ & 0.91 \\
\hline GSI & Response function & \\
\hline Year Round Cabbage (C1) & $y=88.34 * *-0.3180 * x$ & 0.93 \\
\hline Americana Great Lakes (C2) & $y=129.69 * *-0.7235 * * x$ & 0.97 \\
\hline Great Lakes 659 (C3) & $y=129.69 * *-0.7235^{* *} x$ & 0.97 \\
\hline Lucy Brown (C4) & $y=114.32 * *-0.4325 * * x$ & 0.97 \\
\hline Crisp Cabbage (C5) & $y=124.14 * *-0.6730 * * x$ & 0.97 \\
\hline MGT (days) & Response function & \\
\hline Year Round Cabbage (C1) & $y=5.10 * *+0.043^{* *} x-0.0003^{* *} x^{2}$ & 0.99 \\
\hline Americana Great Lakes (C2) & $y=0.37+0.089 * x-0.0005 * x^{2}$ & 0.78 \\
\hline Great Lakes 659 (C3) & $y=1.05^{* *}+0.066^{* *} x-0.0004 * * x^{2}$ & 0.78 \\
\hline Lucy Brown (C4) & $y=2.67 * *+0.083 * * x-0.0004 * * x^{2}$ & 0.97 \\
\hline Crisp Cabbage (C5) & $y=0.88 * *+0.092 * * x-0.0005^{* *} x^{2}$ & 0.84 \\
\hline
\end{tabular}

** and * - Significant at $1 \%$ and $5 \%$ by Student's t-test.

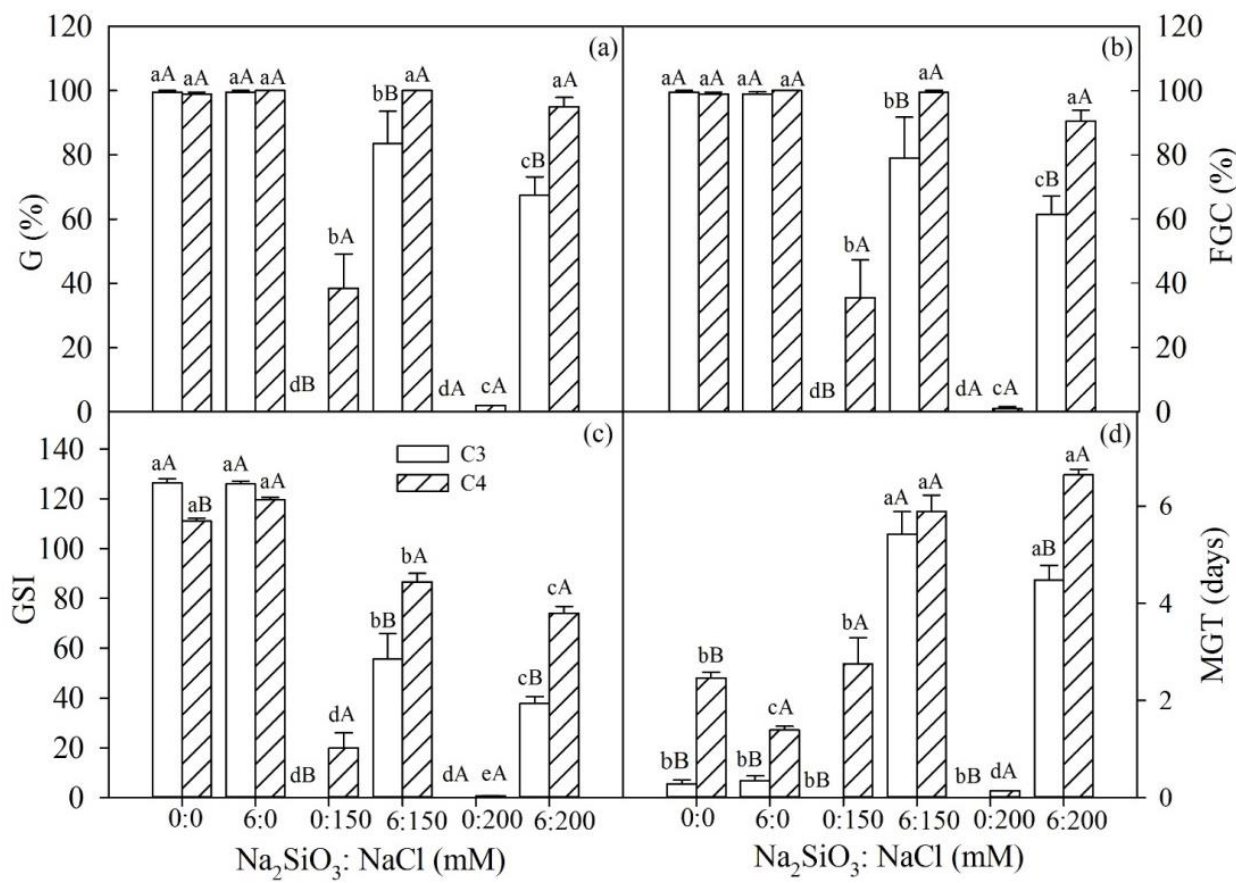

Fig 3. Germination performance in seeds of two lettuce cultivars (C3 - Great Lakes 659 and C4 - Lucy Brown) submitted to different levels of $\mathrm{Na}_{2} \mathrm{SiO}_{3}$ and $\mathrm{NaCl}$ : (a): germination (G), (b): first germination count (FGC), (c): germination speed index (GSI) and (d): mean germination time (MGT). Mean values followed by different lowercase letters between the levels of $\mathrm{Na}_{2} \mathrm{SiO}_{3}$ and $\mathrm{NaCl}_{\text {, and }}$ uppercase letters within the same level of $\mathrm{Na}_{2} \mathrm{SiO}_{3}$ : $\mathrm{NaCl}$ show differences $(p \leq 0.01)$. 
Table 4. Equations for root length (RL), shoot length (SL), root dry weight (RDW) and shoot dry weight (SDW), and coefficient of determination, in seedlings of five lettuce cultivars submitted to different levels of $\mathrm{NaCl}$.

\begin{tabular}{|c|c|c|}
\hline $\mathrm{RL}(\mathrm{cm})$ & Response function & $\mathrm{R}^{2}$ \\
\hline Year Round Cabbage (C1) & $y=3.37 * *-0.0140 * * x$ & 0.99 \\
\hline Americana Great Lakes (C2) & $y=3.83^{* *}-0.0224 * * x$ & 0.88 \\
\hline Great Lakes 659 (C3) & $y=3.53 * *-0.0204 * * x$ & 0.92 \\
\hline Lucy Brown (C4) & $y=3.14-0.139 * * x$ & 0.92 \\
\hline Crisp Cabbage (C5) & $y=3.39 * *-0.0121 * * x$ & 0.91 \\
\hline $\mathrm{SL}(\mathrm{cm})$ & Response function & \\
\hline Year Round Cabbage (C1) & $y=1.96 * *-0.0078 * * x$ & 0.99 \\
\hline Americana Great Lakes (C2) & $y=0.39 * *-0.0020 * * x$ & 0.85 \\
\hline Great Lakes 659 (C3) & $y=0.45^{* *}-0.0024 * * x$ & 0.91 \\
\hline Lucy Brown (C4) & $y=1.26 * *-0.0053^{* *} x$ & 0.87 \\
\hline Crisp Cabbage (C5) & $y=0.48 * *-0.0024 * * x$ & 0.84 \\
\hline RDW (mg) & Response function & \\
\hline Year Round Cabbage (C1) & $y=2.98^{* *}+0.024 * * x-0.0002 * * x^{2}$ & 0.87 \\
\hline Americana Great Lakes (C2) & $y=4.25^{* *}-0.023^{* *} x$ & 0.96 \\
\hline Great Lakes 659 (C3) & $y=3.94 * *-0.008 * * x-0.00007 * * x^{2}$ & 0.92 \\
\hline Lucy Brown (C4) & $y=4.31 * *+0.009 * * x-0.0002 * * x^{2}$ & 0.99 \\
\hline Crisp Cabbage (C5) & $y=4.53^{* *}-0.025^{* *} x$ & 0.97 \\
\hline SDW (mg) & Response function & \\
\hline Year Round Cabbage (C1) & $y=11.18^{* *}+0.067 * * x-0.0004^{* *} x^{2}$ & 0.91 \\
\hline Americana Great Lakes (C2) & $y=6.78^{* *}+0.007 x-0.0002 * * x^{2}$ & 0.89 \\
\hline Great Lakes 659 (C3) & $y=6.59 * *+0.025 * * x-0.0003 * * x^{2}$ & 0.86 \\
\hline Lucy Brown (C4) & $y=10.52 * *+0.094 * * x-0.0007 * * x^{2}$ & 0.93 \\
\hline Crisp Cabbage (C5) & $y=6.54 * *+0.041^{* *} x-0.0004 * * x^{2}$ & 0.85 \\
\hline
\end{tabular}

** and * - Significant at $1 \%$ and $5 \%$ by Student's t-test.

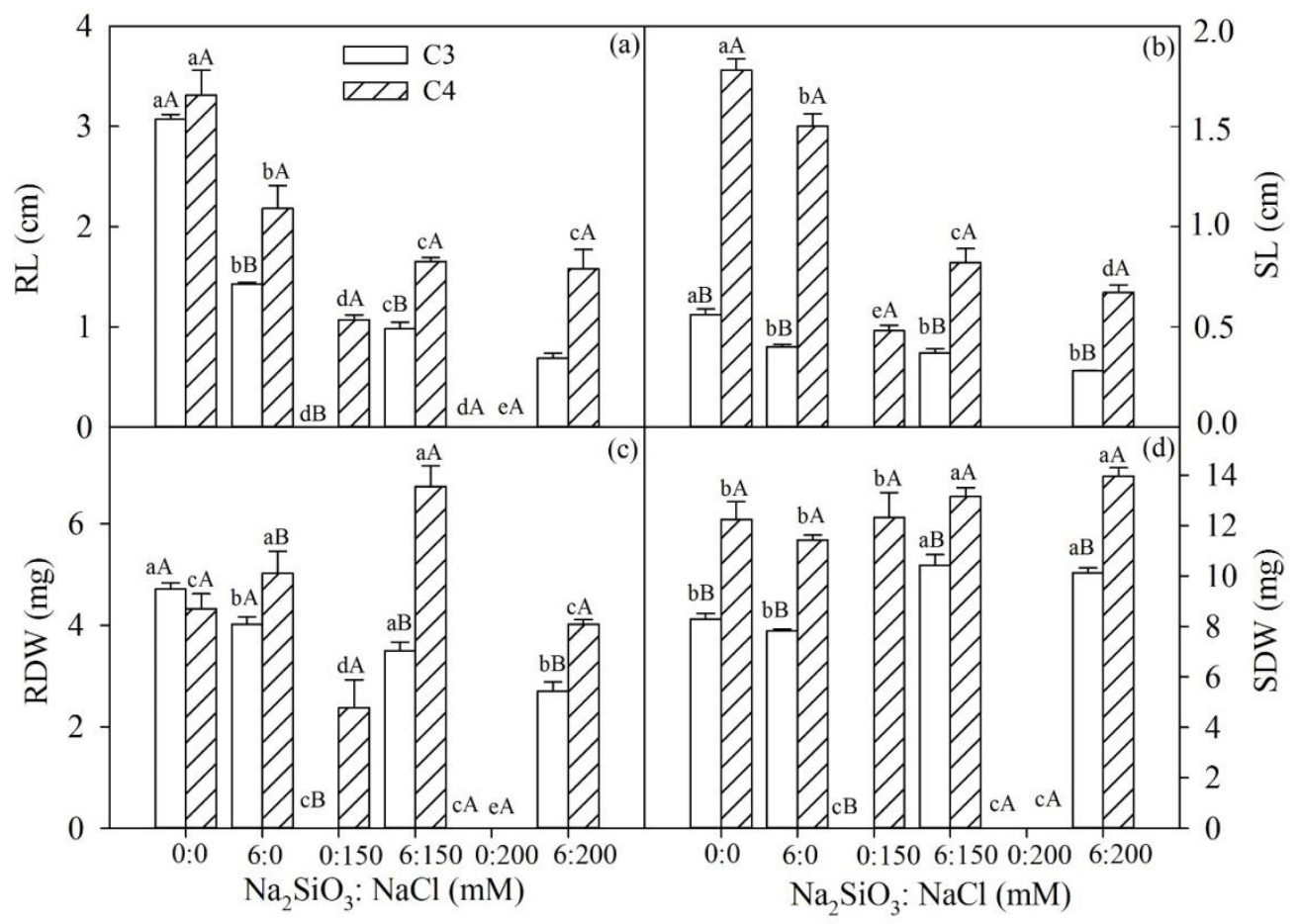

Fig 4. Initial growth in seedlings of two lettuce cultivars (C3 - Great Lakes 659 and C4 - Lucy Brown) submitted to different levels of $\mathrm{Na}_{2} \mathrm{SiO}_{3}$ and $\mathrm{NaCl}$ : (a): root length (RL), (b): shoot length (SL), (c): root dry weight (RDW) and (d): shoot dry weight (SDW). Mean values followed by different lowercase letters between the levels of $\mathrm{Na}_{2} \mathrm{SiO}_{3}$ and $\mathrm{NaCl}$, and uppercase letters within the same level of $\mathrm{Na}_{2} \mathrm{SiO}_{3}: \mathrm{NaCl}$ show differences $(\mathrm{p} \leq 0.01)$. 
For root length $(\mathrm{RL})$ and shoot length $(\mathrm{SL})$, there was a linear fit as a function of salt level for all cultivars (Figure 2a, b), with a decrease in both roots and shoots for increases in $\mathrm{NaCl}$ concentration. This behaviour was also found by Bernardes et al. (2015) in cabbage seedlings, where increased salt stress reduced seedling development in batches of both high and low viability, decreasing the length of the shoots and roots at the highest stress levels. Similarly, when working with different accessions of the melon (Cucumis melo L.) from the cultivars 'Gaúcho Redondo' and 'AF682', Secco et al. (2010) found a reduction in total seedling length under salt stress.

Root dry weight (RDW) followed a quadratic model, except for the cultivars 'Americana Great Lakes' and 'Crisp Cabbage', which best fit the linear regression model (Figure 2c). The point of maximum dry weight accumulation in the roots for $\mathrm{C} 1$ was found at $60 \mathrm{mM}$ with $3.57 \mathrm{mg}$, and for $\mathrm{C} 4$ at $22.5 \mathrm{mM}$, with $4.41 \mathrm{mg}$. For shoot dry weight (SDW), quadratic behaviour for the levels of $\mathrm{NaCl}$ was seen in the cultivars, with maximum accumulation at concentrations of 83.75 and $67.14 \mathrm{mM}$ for the cultivars $\mathrm{C} 1$ and $\mathrm{C} 4$ respectively (Figure 2d). Agreeing with these results, Bernardes et al. (2015) found a quadratic adjustment for this variable in cabbage seeds treated with $\mathrm{NaCl}$, with a drastic reduction in mean values from $-1.0 \mathrm{MPa}$. In the present work this was found beginning at $100 \mathrm{mM}$.

When working with salinity in melon seeds, Secco et al. (2010) saw a reduction in the dry matter weight of the seedlings. This is probably due to the effect of the high concentration of sodium chloride on the mechanisms of hydrolysis and mobilisation of reserves in the seedlings (Pedó et al., 2014).

The cultivars displayed varying responses to the stress, with some being more tolerant, as seen with cultivars $\mathrm{C} 1$ and $\mathrm{C} 4$, and others more sensitive, as was confirmed for the cultivars C2, C3, and 'Crisp Cabbage' (C5). Such varying behaviour agrees with Oliveira and Gomes Filho (2009), who evaluated the effects of water stress and salt stress on seed germination and vigour in two genotypes of forage sorghum, and found that different genotypes present different responses as a function of water deficit and salinity of the environment.

\section{The effect of silicon on seed germination and initial growth in lettuce seedlings under salt stress}

It was seen that stress caused by sodium chloride $(\mathrm{NaCl})$ affected germination (G), first germination count (FGC), germination speed index (GSI), and mean germination time (MGT) in both cultivars (Figure $3 a, b, c, d$ ). When sodium silicate $\left(\mathrm{Na}_{2} \mathrm{SiO}_{3}\right)$ was added as the source of silicon, there was no difference from the control treatment, but when added in the presence of $\mathrm{NaCl}$, a definite reduction was seen in the deleterious effects of the salinity, with a satisfactory performance being found for germination and speed of germination in the cultivars. Thus, at levels of 150 and 200 $\mathrm{mM} \mathrm{NaCl}$, there was practically no germination in the lettuce, but when $\mathrm{Na}_{2} \mathrm{SiO}_{3}$ was added at these concentrations, the cultivars displayed satisfactory values for $\mathrm{G}$ and $\mathrm{GSI}$, proving that the use of $\mathrm{Si}$ is able to produce a significant reduction in the deleterious effects of $\mathrm{NaCl}$ on seed germination and germination speed. This information shows that the beneficial effect of silicon on plants is far more evident under conditions that are stressful to the plants (Rizwan et al., 2015). For the length and dry weight of the roots and shoots, similar behaviour was observed to that of the germination variables, where the seedlings showed reduced growth under conditions of stress caused by the $\mathrm{NaCl}\left(150\right.$ and $200 \mathrm{mM}$ ), however, when the $\mathrm{Na}_{2} \mathrm{SiO}_{3}$ was added to the solution, the seedlings grew and produced a greater amount of dry weight, confirming the beneficial effect of Si on the initial growth of seedlings exposed to $\mathrm{NaCl}$ (Figure $4 a, b, c, d$ ). The beneficial effect of silicon on the germination and growth of lettuce seedlings under salt stress agrees with that already verified in other crops. In sorghum plants grown under salt stress, Kafi et al. (2011) found that an increase in the silicon dose gave a greater production of shoot dry weight. Agreeing with the results of the present work, such crops as maize (Lima et al., 2011), wheat (Tuna et al., 2008; Gurmani et al., 2013), and rapeseed (Farshidi et al., 2012) subjected to salt stress, also showed better growth when supplemented with siliconbased fertiliser. At the highest concentrations of $\mathrm{NaCl}$, when Si was added, greater values were seen for G, GSI, FGC and MGT in the lettuce seeds, and RL, SL, RDW and SDW in the seedlings. This behaviour was also seen in the tomato, where treatment with $\mathrm{N}-\mathrm{SiO} 2$ increased germination percentage, mean germination time and germination index in the seeds (Haghighi et al., 2012, Siddiqui and Al-Whaibi, 2014). In tomato seedlings, Almutairi (2016) suggested that the greater capacity for tolerating salt stress of seedlings that received $\mathrm{Si}$ could be related to the transcription and activation of response genes to this type of stress. Similar behaviour may have occurred in the present study with the lettuce seedlings. In a study with Cucurbita pepo L., Siddiqui et al. (2014) found that treatment with N-Si was able to reduce the inhibitory effects of salt stress and increase germination and growth characteristics, with a reduction in the levels of malondialdehyde, hydrogen peroxide $\left(\mathrm{H}_{2} \mathrm{O}_{2}\right)$ and electrolyte leakage, which may also have occurred in this work. According to Liang et al. (2007), sodium concentrations in the roots of rice and barley, as well as the transport of sodium to the shoots, were reduced by the addition of silicon, while the absorption and transport of $\mathrm{K}^{+}$ were increased. Among other benefits, silicon also increases the leaf and root activity of oxidative stress enzymes, which possibly occurred in the lettuce cultivars evaluated in this work. Since an increase in antioxidant activity leads to a reduction in lipid peroxidation of the plasma membrane of plants under salt stress, the Si may have affected the structure, integrity and function of the plasma membrane (Zhu et al., 2004; Al-Aghabary et al., 2004; Liang et al., 2007).

\section{Materials and methods}

Two experiments were carried out in the Seed Analysis Laboratory of the Department of Plant Technology at the Federal University of Ceará, from March to May of 2016.

\section{Experiment I - Lettuce cultivars under different conditions of salinity}

\section{Plant material and conducting the experiment}

The seeds of five commercial cabbage-type lettuce cultivars were used, all with high germination capacity of over $90 \%$, 
were used. Carried out with four replications of 50 seeds distributed evenly over two sheets of seed-germination filter paper moistened with distilled water in a proportion of 3 times the weight of the dry paper, and arranged in $10 \times 1.5$ $\mathrm{cm}$ petri dishes. The seeds were kept in a biochemical oxygen demand (BOD) germination chamber under an alternating light regime (12 hours with light and 12 hours with no light) and at a fixed temperature of $20^{\circ} \mathrm{C}$ (Brasil, 2009). The substrate was moistened with distilled water, only on the day test was set up to avoid changes in concentration.

\section{Treatments and experimental design}

The experiment was carried out in a completely randomised design, following a $5 \times 5$ factorial scheme with four replications of 50 seeds. The first factor consisted of five lettuce cultivars, Year Round Cabbage (C1), Americana Great Lakes (C2), Great Lakes 659 (C3), Lucy Brown (C4) and Crisp Cabbage (C5); the second factor corresponded to five levels of $\mathrm{NaCl}(0.0,50,100,150$ and $200 \mathrm{mM})$ in the germination substrate. To achieve the different levels of salt, sodium chloride $(\mathrm{NaCl})$ was used diluted in distilled water. For the control treatment only distilled water was used to moisten the substrate. A benchtop conductivity meter with temperature correction was used to verify the concentration of the solutions used for moistening the substrate.

\section{Evaluated characteristics}

Germination (G) - Percentage germination was evaluated seven days after the start of the test, as per Brazil (2009). Seeds showing a primary root $\geq 2 \mathrm{~mm}$ were considered to have germinated.

First germination count (FGC) - carried out together with the germination test, calculating the mean percentage of germinated seeds on the fourth day of the test, as recommended by Brazil (2009).

Germination speed index (GSI) - carried out simultaneously with the tests for germination, calculating at the same time each day the number of seeds that displayed a primary root $\geq 2 \mathrm{~mm}$, as per Maguire (1962). where: $\mathrm{GSI}=\left(\mathrm{G}_{1} / \mathrm{N}_{1}\right)+$ $\left(\mathrm{G}_{2} / \mathrm{N}_{2}\right)+\left(\mathrm{G}_{3} / \mathrm{N}_{3}\right)+\ldots+(\mathrm{Gn} / \mathrm{Nn})$; and where: $\mathrm{GSI}=$ germination speed index; $G_{1}, G_{2}, G_{3}, \ldots, G$ n = number of germinated seeds included in the first, second, third and nth counts; $\mathrm{N}, \mathrm{N}_{2}, \mathrm{~N}_{3}, \ldots, \mathrm{Nn}$ = number of days from planting to the first, second, third and nth counts.

Mean germination time (MGT) - calculated from the daily counts up to the seventh day after sowing, as per Labouriau (1983), with the results expressed in days. Where: MGT $=(\Sigma$ ni.ti) / ( $\Sigma$ ni); and where: ni; number of germinated seeds per day, ti; incubation time (days).

Using the same seedlings as for the previous characteristics, the 15 most uniform seedlings from each replication were selected on the seventh day after sowing, when they were separated into roots and shoots and the following determined:

Root length (RL) and shoot length (SL) - measurements were taken of the seedlings after the final count of the germination test using a graduated ruler, with the results expressed in $\mathrm{cm}$ seedling ${ }^{-1}$. The results were summed, and divided by the number of samples ( 15 seedlings), to give the mean root and shoot length per seedling.
Root dry weight (RDW) and shoot dry weight (SDW) normal seedlings from each replication were packed in paper bags and heated in an oven at $65^{\circ} \mathrm{C}$ to constant weight. The samples were then weighed on a precision scale $(0.0001 \mathrm{~g})$, with the results expressed in $\mathrm{mg}$ seedling ${ }^{-1}$.

\section{Experiment II - Silicon tolerance to salt stress in lettuce}

\section{Plant material and conducting the experiment}

In this experiment, a tolerant cultivar ('Lucy Brown') and a sensitive cultivar to salt stress ('Great Lakes 659') were used. These cultivars were selected from experiment I; in addition, the two concentrations of $\mathrm{NaCl}$ were used that had the most detrimental effects on germination and on initial seedling growth in experiment $I$, both in the presence and absence of $\mathrm{Si}$. This experiment was conducted in the same way as experiment $\mathrm{I}$.

\section{Treatments and experimental design}

The experiment was conducted in a completely randomised design with four replications in a $2 \times 6$ factorial scheme of two lettuce cultivars (Great Lakes 659 and Lucy Brown) and six combined concentrations of sodium silicate $\left(\mathrm{Na}_{2} \mathrm{SiO}_{3}\right)$ and $\mathrm{NaCl}\left(0.0 \mathrm{mM} \mathrm{Na}_{2} \mathrm{SiO}_{3}\right.$ and $\mathrm{NaCl}, 6.0 \mathrm{mM} \mathrm{Na}_{2} \mathrm{SiO}_{3}+0.0 \mathrm{mM}$ $\mathrm{NaCl}, 0.0 \mathrm{mM} \mathrm{Na}_{2} \mathrm{SiO}_{3}+150 \mathrm{mM} \mathrm{NaCl}, 6.0 \mathrm{mM} \mathrm{Na}_{2} \mathrm{SiO}_{3}+$ $150 \mathrm{mM} \mathrm{NaCl}, 0.0 \mathrm{mM} \mathrm{Na} \mathrm{SiO}_{3}+200 \mathrm{mM} \mathrm{NaCl}, 6.0 \mathrm{mM}$ $\mathrm{Na}_{2} \mathrm{SiO}_{3}+200 \mathrm{mM} \mathrm{NaCl}$ ). The cultivars and the $\mathrm{NaCl}$ concentrations used in the experiment were selected based on the results of experiment $\mathrm{I}$, and using the cultivars considered sensitive to stress (Great Lakes 659) and tolerant to stress (Lucy Brown), and the $\mathrm{NaCl}$ concentrations that most affected germination and growth of the seedlings.

The characteristics under evaluation were the same as in experiment $\mathrm{I}$.

\section{Statistical analysis}

The results were submitted to the Shapiro-Wilk test for normality. After verifying the lack of data normality, the germination data were transformed by $\arcsin (x / 100)^{1 / 2}$ and those for initial growth by root $(x+0.5)$. An analysis of variance was then carried out by F-test. The Scott-Knott test was used to compare mean values between the qualitative factor (cultivar), with regression analysis being used for the quantitative factor (levels of $\mathrm{NaCl}$ ). Statistical analysis of the data was carried out using the SISVAR $^{\circledR} 5.6$ software (Ferreira, 2011).

\section{Conclusion}

The lettuce cultivars under study showed different effects on germination and initial plant growth when submitted to salt stress; in this study 'Lucy Brown' and 'Year Round Cabbage' were the most tolerant to the effects of such stress.

In addition, it was found that Si improved germination and initial growth in the seedlings under conditions of high salinity, and could therefore be considered as reducing the harmful effects of salinity in lettuce during the initial stages of growth and development. 


\section{Acknowledgements}

The authors wish to thank the National Council for Scientific and Technological Development (CNPq) for the scholarships awarded to the first two authors. The authors would also like to thank the staff of the UFC Seed Analysis Laboratory for their support during this research.

\section{References}

Al-Aghabary K, Zhu Z, Shi Q (2004) Influence of silicon supply on chlorophyll content, chlorophyll fluorescence, and antioxidative enzyme activities in tomato plants under salt stress. J Plant Nutr. 27 (12): 2101-2115.

Almutairi ZM (2016) Effect of nano-silicon application on the expression of salt tolerance genes in germinating tomato (Solanum lycopersicum L.) seedlings under salt stress. POJ. 9(1):106-114.

Bernardes PM, Mengarda LHG, Lopes JC, Nogueira MU, Rodrigues LL (2015) Qualidade fisiológica de sementes de repolho de alta e baixa viabilidade sob estresse salino. Nucleus. 12 (1):77- 86.

Brasil (2009) Ministério da Agricultura, Pecuária e Abastecimento. Regras para análise de sementes. Brasília.

Bray EA, Bailey-Serres J, Weretilnyk E (2015) Responses to abiotic stresses. In: Buchanan B, Gruissem W, Jones RL (ed). Biochemistry and Molecular Biology of Plants. Rockville: Wiley Blackwell: 1158-1203.

Farshidi M, Abdolzadeh A, Sadeghipou RHR (2012) Silicon nutrition alleviates physiological disorders imposed by salinity in hydroponically grown canola (Brassica napus L.) plants. Acta Physiol Plant. 34 (5): 1779-1788.

Ferreira DF (2011) Sisvar: A computer statistical analysis system. Cien Agrotec. 35 (6): 1039-1042.

Gurmani AR, Bano A, Najeeb U, Zhang J, Khan SU, Flowers TJ (2013) Exogenously applied silicate and abscisic acid ameliorates the growth of salinity stressed wheat (Triticum aestivum L.) seedlings through $\mathrm{Na}^{+}$exclusion. Aust J Crop Sci. 7 (8): $1123-1130$.

Gupta B, Huang H (2014) Mechanism of salinity tolerance in plants: physiological, biochemical, and molecular characterization. Int J Genomics. 2014 (1): 1-19.

Haghighi M, Afifipour Z, Mozafarian M (2012) The effect of N-Si on tomato seed germination under salinity levels. J Biol Environ Sci. 6(16): 87-90.

Kafi M, Nabati J, Masoumi A, Mehrgerdi MZ (2011) Effect of salinity and silicon application on oxidative damage of sorghum [Sorghum bicolor (L.) moench.]. Braz J Bot. 43 (5): 2457-2462.

Kraska JE, Breitenbeck GA (2010) Survey of the silicon status of flooded rice in Louisiana. Agron J. 102 (2): 523-529.

Labouriau LGA (1983) Germinação das sementes. Washington: Secretaria Geral da Organização dos Estados Americanos 174.

Liang Y, Sun W, Zhu YG, Christie P (2007) Mechanisms of siliconmediated alleviation of abiotic stresses in higher plants: $A$ review. Environ Pollut. 147 (2): 422-428, 2007.

Lima MA, Castro VF, Vidal JB, Enéas-Filho J (2011) Aplicação de silício em milho e feijão-de-corda sob estresse salino. Rev Cienc Agron. 42 (2):398- 403.

Lopes JC, Macedo CMP (2008) Germinação de sementes de couve chinesa sob influência do teor de água, substrato e estresse salino. Rev Bras Sem. 30 (3): 79- 85.
Maguire JD (1962) Speed of germination-aid in selection and evaluation for seedling emergence and vigor. Crop Sci. 2 (1): 176- 177

Miranda JRP, Carvalho JG, Freire ALO, Fernandes AR (2010) Avaliação do silício como atenuador dos efeitos da salinidade na nutrição mineral de clones de Anacardium occidentale L. Eng Ambiental. 7 (3): 144- 156.

Munns R, Tester M (2008) Mechanisms of salinity tolerance. Annu rev plant biol. 59 (1): 651-81.

Nasri N, Saidi I, Kaddour R, Lachaâl M (2015) Effect of salinity on germination, seedling growth and acid phosphatase activity in lettuce. Am J Plant Sci. 6 (1): 57-63.

Oliveira AB, Gomes Filho E (2009) Germinação e vigor de sementes de sorgo forrageiro sob estresse hídrico e salino. Rev Bras Sem. 31 (3): 48-56.

Pedó T, Aisenberg GR, Aumonde TZ, Villela FA (2014) Desempenho fisiológico de sementes e plântulas de genótipos de cucurbitaceae e solanaceae em ambiente salino. Tec Cien Agrop. 8 (2): 1-7.

Rabbani ARC, Mann RS, Ferreira RA, Carvalho SVA, Nunes FBS, Brito AS (2013) Efeito do estresse salino sobre atributos da germinação de sementes de girassol. Sci Plena. 9 (5): 5-10.

Rizwan M, ALI S, Ibrahim M, Farid M, Adrees M, Bharwana AS, Rehman MZ, Qayyum MF, Abbas F (2015) Mechanisms of silicon-mediated alleviation of drought and salt stress in plants: a review. Environ Sci Pollut Res. 22 (1): 15416-15431.

Rodrigues FA, Oliveira LA, Korndorfer AP, Korndorfer GH (2011) Silício: um elemento benéfico e importante para as plantas. Infor Agron. 134 (1): 14-20.

Santos ARF, Mann RS, Ferreira RA, Brito AS (2011) Water prehydration as priming for moringa oleifera lam. seeds under salt stress. Trop Subtrop Agroecosyst.14 (1): 201-207.

Secco LB, Queiroz SO, Dantas BF, Souza YA, Silva PP (2010) Qualidade de sementes de acessos de melão (Cucumis melo L.) em condições de estresse salino. Rev V Agroecol Desenv Sustent. 5 (2): 1-11.

Sivanesan I, Son MS, Jeong BR (2011) Effect of soaking of seeds in potassium silicate and uniconazole on germination and seedling growth of tomato cultivars, seogeon and seokwang. Afr J Biotechnol. 10 (35): 6743-6749.

Siddiqui MH, Al-Whaibi MH, Faisal M, Al Sahli AA (2014) Nanosilicon dioxide mitigates the adverse effects of salt stress on Cucurbita pepo L. Environ Toxicol Chem. 33(11): 2429-37.

Siddiqui MH, Al-Whaibi MH (2014) Role of nano- $\mathrm{SiO}_{2}$ in germination of tomato (Lycopersicum esculentum seeds Mill.). Saudi J Biol Sci. 21(1): 13-17.

Tuna AL, Kaya C, Higgs D, Amador BM, Aydemir S, Girgin AR (2008) Silicon improves salinity tolerance in wheat plants. Environ Exp Bot. 62 (1): 10-16.

Wang XD, Ou-yang C, Fan Z, Gao S, Chen F, Tang L (2010) Effects of exogenous silicon on seed germination and antioxidant enzyme activities of Momordica charantia under salt stress. J Anim Plant Sci. 6 (3): 700- 708.

Yokoi S, Quintero FJ, Cubero B, Ruiz MT, Bressan RA, Hasegawa PM, Pardo JM (2002) Differential expression and function of arabidopsis thaliana $\mathrm{NHX} \mathrm{Na} / \mathrm{H}^{+}$antiporters in the salt stress response. Plant J. 30 (1): 529-539.

Zhu Z, Wei G, Li J, Qian Q, Yu J (2004) Silicon alleviates salt stress and increases antioxidant enzymes activity in leaves of saltstressed cucumber (Cucumis sativus L.). Plant Sci. 167 (3): 527 533. 